\title{
Liver-function Tests during Intake of Contraceptive Tablets in Pre-menopausal Women
}

\author{
A. EISALO,* M.D. ; P. A. JÄRVINEN,* M.D. ; T. LUUKKAINEN,* M.D.
}

Brit. med. F., 1965, 1, 1416-1417

There have been conflicting reports on the results of liverfunction tests in women taking contraceptive tablets. In a previous study (Eisalo et al., 1964) in post-menopausal women elevated serum levels of glutamic oxaloacetic transaminase and glutamic pyruvic transaminase were found in every case, whereas other workers (Swaab, 1964 ; Linthorst, 1964) found no evidence of abnormal liver function in pre-menopausal women. The present study was therefore undertaken in an attempt to explain this apparent discrepancy.

\section{Material and Methods}

We studied 109 women between the ages of 17 and 52 (average age 29.4 years). None had a history or evidence of hepatic or biliary disease. Volidan (4 mg. 17 $\alpha$-acetoxy-6methylpreg-4,6-dien-3,20-dione and $0.05 \mathrm{mg}$. 17 $\alpha$-ethinyloestradiol) and Lyndiol (5 mg. $17 \alpha$-ethynyloestrenol and 0.15 mg. 3-methoxy-17 $\alpha$-ethinyloestradiol) were given for contraception to 45 and 39 women respectively as one tablet daily for 20 days in every menstrual cycle. Orgametril (17 $\alpha$ ethynyloestrenol), the progestogen component of Lyndiol, was administered as one 5-mg. tablet daily for 40 to 420 days to 25 women as treatment for various gynaecological disorders, mostly endometriosis.

The following liver-function tests were performed: serum glutamic oxaloacetic transaminase (S.G.O.T., normal less than 4) Wroblewski (1958) units), serum glutamic pyruvic transaminase (S.G.P.T., normal less than 40 Wroblewski units), alkaline phosphatase (normal 0.8-2.9 Bessey-Lowry (Bessey et al., 1946) units), serum bilirubin (normal less than $1.2 \mathrm{mg} . /$ $100 \mathrm{ml}$.), thymol turbidity (normal less than 4 MacLagan units), and bromsulphthalein retention (normal less than $7 \%$ at 45 minutes after the intravenous injection of B.S.P. $5 \mathrm{mg} . /$ kg. body weight). The tests were performed at 8 a.m. after overnight fasting during the last week of each 20-day course of contraception, or at three-monthly intervals in the Orgametril series. When an abnormal result was obtained, the

- University Department of Obstetrics and Gynaecology, Central Hospital, Helsinki, Finland. treatment was discontinued and the liver-function tests were repeated four weeks later.

\section{Results}

As can be seen from Table I, the average age of the women who were treated for contraception was below 30 . Serumtransaminase levels were raised in $2(4.2 \%)$ out of 45 cases in the Volidan group and in $7(17.9 \%)$ out of 39 in the Lyndiol group. Serum alkaline phosphatase was found to be raised in only one subject in each group (2.3\% and $2.7 \%$ respectively), and the serum bilirubin was normal in every case. In contrast, the bromsulphthalein retention was abnormal in $8(19 \%)$ out of 42 cases in the Volidan group and in $48 \%$ of those in the Lyndiol group. The thymol turbidity was the only abnormal liver-function test in $2(4.6 \%)$ out of 43 subjects in the Volidan group.

The patients in the Orgametril group were on the average older and took a greater number of tablets than subjects in the other groups. The incidence of abnormal findings was essentially the same as in the Volidan group, but considerably lower than in the Lyndiol group.

Table II analyses in greater detail the cases in which the S.G.O.T. and S.G.P.T. levels and the B.S.P. retention were abnormal. It is interesting to observe that in the case of any one drug the average age of patients with abnormal B.S.P. retention is slightly higher than that of the whole group, but the difference is not statistically significant $(P>0.05)$.

No symptoms due to the tablets were encountered among the patients with abnormal liver-function tests, and the tests always returned to normal within four weeks of withdrawal of the drug.

\section{Discussion}

The age of patients taking oral contraceptive drugs appears to exert a significant influence on the incidence of abnormal liver function. In the present study raised serum-transaminase levels occurred in $9 \%$ of all cases, and the B.S.P. retention was abnormal in $29 \%$.

\begin{tabular}{|c|c|c|c|c|c|c|c|c|c|c|}
\hline \multicolumn{2}{|l|}{ Drug } & $\begin{array}{c}\text { No. of } \\
\text { Cases }\end{array}$ & $\begin{array}{c}\text { Age in Years } \\
\text { (Mean) }\end{array}$ & $\begin{array}{l}\text { No. of Pills } \\
\text { (Mean) }\end{array}$ & S.G.O.T. & S.G.P.T. & $\begin{array}{c}\text { Alkaline } \\
\text { Phosphatase }\end{array}$ & Bilirubin & B.S.P. & $\begin{array}{l}\text { Thymol } \\
\text { Turbidity }\end{array}$ \\
\hline $\begin{array}{ll}\text { Volidan } \\
\text { l.yndiol } \\
\text { Orgametril }\end{array}$ & $\because$. & $\begin{array}{l}45 \\
39 \\
25\end{array}$ & $\begin{array}{l}21-41(28 \cdot 5) \\
17-40(27 \cdot 0) \\
23-52(34 \cdot 3)\end{array}$ & $\begin{array}{l}40-180(75) \\
40-200(100) \\
40-420(149)\end{array}$ & $\begin{array}{l}45 / 0^{*} \\
38 / 6 \\
25 / 1\end{array}$ & $\begin{array}{l}45 / 2 \\
39 / 7 \\
24 / 1\end{array}$ & $\begin{array}{l}44 / 1 \\
37 / 1 \\
25 / 0\end{array}$ & $\begin{array}{l}42 / 0 \\
35 / 0 \\
22 / 1 \\
\end{array}$ & $\begin{array}{l}42 / 8 \\
29 / 14 \\
20 / 4\end{array}$ & $\begin{array}{l}43 / 2 \\
29 / 0 \\
24 / 1\end{array}$ \\
\hline & & 109 & $(29 \cdot 4)$ & & $108 / 7$ & $108 / 10$ & $106 / 2$ & $99 / 1$ & $91 / 26$ & $96 / 3$ \\
\hline
\end{tabular}

- Numerator is total number of cases and denominator the number abnormal.

TABLE II.-Raised Levels of S.G.O.T., S.G.P.T., and B.S.P. Retention

\begin{tabular}{|c|c|c|c|c|c|c|c|c|c|c|c|c|}
\hline \multirow[b]{2}{*}{ Drug } & \multicolumn{4}{|c|}{ S.G.O.T. } & \multicolumn{4}{|c|}{ S.G.P.T. } & \multicolumn{4}{|c|}{ B.S.P. Retention } \\
\hline & $\begin{array}{l}\text { No. } \\
\text { of } \\
\text { Cases }\end{array}$ & $\begin{array}{l}\text { Age in } \\
\text { Years } \\
\text { (Mean) }\end{array}$ & $\begin{array}{l}\text { No. of } \\
\text { Pills } \\
\text { (Mean) }\end{array}$ & $\begin{array}{l}\text { Wroblewski } \\
\text { Units } \\
\text { (Mean) }\end{array}$ & $\begin{array}{l}\text { No. } \\
\text { of } \\
\text { Cases }\end{array}$ & $\begin{array}{l}\text { Age in } \\
\text { Years } \\
\text { (Mean) }\end{array}$ & $\begin{array}{l}\text { No. of } \\
\text { Pills } \\
\text { (Mean) }\end{array}$ & $\begin{array}{l}\text { Wroblewski } \\
\text { Units } \\
\text { (Mean) }\end{array}$ & $\begin{array}{l}\text { No. } \\
\text { of } \\
\text { Cases }\end{array}$ & $\begin{array}{l}\text { Age in } \\
\text { Years } \\
\text { (Mean) }\end{array}$ & $\begin{array}{l}\text { No. of } \\
\text { Pills } \\
\text { (Mean) }\end{array}$ & $\begin{array}{l}\text { Retention } \\
\text { in \% } \\
\text { (Mean) }\end{array}$ \\
\hline $\begin{array}{l}\text { Volidan } \ldots \\
\text { Lyndiol } \ldots \\
\text { Orgametril }\end{array}$ & $\begin{array}{r}-6 \\
1\end{array}$ & $\overline{24-32(27 \cdot 7)}$ & $\begin{array}{c}40-200 \\
170\end{array}$ & $43-\overline{49}(58)$ & $\begin{array}{l}2 \\
7 \\
1\end{array}$ & $\begin{array}{c}26-32(29) \\
24-32(27 \cdot 3) \\
23\end{array}$ & $\begin{array}{c}60-60(60) \\
40-200(113) \\
170\end{array}$ & $\begin{array}{c}52-73(62 \cdot 5) \\
41-115(68 \cdot 2) \\
69\end{array}$ & $\begin{array}{r}8 \\
14 \\
4\end{array}$ & $\begin{array}{l}21-41(30 \cdot 5) \\
22-34(29 \cdot 2) \\
23-52(34 \cdot 5)\end{array}$ & $\begin{array}{r}40-180(90) \\
40-200(106) \\
90-360(180)\end{array}$ & $\begin{array}{c}7 \cdot 1-12 \cdot 6(9 \cdot 9) \\
7 \cdot 1-15 \cdot 1(9 \cdot 9) \\
9 \cdot 5-14 \cdot 9(12 \cdot 6)\end{array}$ \\
\hline
\end{tabular}


It is uncertain whether the abnormal findings indicate impaired liver function. It has been suggested that they may be a result of the pseudopregnancy state (Tyler, 1964). 'While the B.S.P.-removal mechanisms have been found to be impaired in normal pregnancy (Combes et al., 1963), the serum-transaminase levels and the standard B.S.P. retention are not abnormal (Christhilf et al., 1950 ; Combes et al., 1963 ; Ikonen, 1964). Mueller and Kappas (1964) in their patients, who were mostly post-menopausal, showed that natural oestrogens increased B.S.P. retention, but did not affect serumtransaminase levels. Lyndiol, with an oestrogenic component of $0.15 \mathrm{mg}$. per tablet, provoked abnormal serum-transaminase levels and B.S.P. retention more often than did Volidan with only $0.05 \mathrm{mg}$. of $17 \alpha$-ethinyloestradiol per tablet. This may be merely due to the fact that Lyndiol contains three times as much oestrogen as Volidan, but it is also possible that the 3-methoxy radical potentiates the effect of oestrogen on the liver. On the other hand, $17 \alpha$-ethynyloestrenol itself or one of its metabolites may also be an active principle. There is evidence that in man 19-norsteroids are converted into oestrogenic compounds (Goldzieher, 1964), and the progestogen component of Lyndiol might in this way potentiate the effect of synthetic oestrogen on the liver. It seems likely that oestrogens interfere with the transport of B.S.P. through the liver but not with its conjugation (Mueller and Kappas, 1964), as evidenced by the abnormally low B.S.P. clearance in post-menopausal women treated with oral contraceptives (Eisalo et al., 1964). Finally, it was surprising to find an almost identical incidence of abnormal results in the Orgametril and Volidan groups.

In conclusion, the serum transaminase levels and the B.S.P. retention should be determined in women taking oral contraceptive drugs, and withdrawal of medication should be considered in the event of abnormal results.

\section{Summary}

The incidence of abnormal liver-function tests was studied in 109 pre-menopausal women (mean age 29.4 years) taking contraceptive tablets.

Volidan was given to 45 women and Lyndiol to 39 women aged 17-41 years for contraception. Orgametril was administered therapeutically to 25 women aged 23-52. Standard liver-function tests were performed at regular intervals in every case.

The same low incidence of abnormal results was found in the Volidan and Orgametril groups, where serum-transaminase levels were raised in $4 \%$ of women and the bromsulphthalein retention was increased in $19 \%$. In the Lyndiol group, however, the incidence was much higher, with raised serum-transaminase levels in $18 \%$ of cases and increased B.S.P. retention in $48 \%$. In all cases the liver-function tests returned to normal within four weeks of withdrawal of the drug.

The above investigation was supported by a grant from the Sigrid Juselius Foundation.

\section{REFERENCES}

Bessey, O. A., Lowry, O. H., and Brock, M. J. (1946). F. biol. Chem., 164,321 .

Christhilf, S. M., and Bonsnes, R. W. (1950). Amer. F. Obstet. Gynec., 59,1100 .

Combes, B., Shibata, H., Adams, R., Mitchell, B. D., and Trammell, V. (1963). अ. S. clin. Invest., 42, 1431.

Eisalo, A., Järvinen, P. A., and Luukkainen, T. (1964). Brit. med. f., $2,426$.

Goldzieher, J. W. (1964). Med. Clin. N. Amer., 48, 529.

Ikonen, E. (1964). Acta obstet. gynec. scand., 43, Suppl. No. 5.

Linthorst, G. (1964). Brit. med. ₹., 2, 920.

Mueller, M. N., and Kappas, A. (1964). $尹$. clin. Invest., 43, 1905.

Swaab, L. I. (1964). Brit. med. 7., 2, 755 .

Tyler, E. T. (1964). Ibid., 2, 843.'

Wroblewski, F. (1958). In Advances in Clinical Chemistry, edited by H. Sobotka and C. P. Stewart, vol. 1, p. 313. Academic Press Inc., N.Y.

\title{
Stimulation of Gastric Intrinsic Factor Secretion
}

\author{
S. ARDEMAN,* M.A., B.M. ; I. CHANARIN, $\dagger$ M.D., D.C.P.
}

Brit. med. F., 1965, 1, 1417-1418

The parasympatheticomimetic drug carbachol when given to some patients with gastric atrophy increases the absorption of vitamin $B_{12}$ (Whiteside, Mollin, Coghill, Williams, and Anderson, 1964; Baker and Mollin, 1955). It was suggested, therefore, that carbachol stimulated the secretion of gastric intrinsic factor, and some support for this suggestion came from the report that it increased the concentration in gastric juice of substances binding vitamin $B_{12}$ (Gullberg, 1960). A similar increase in the vitamin- $B_{12}$-binding capacity of gastric juice after injection of methacholine (Mecholyl) was reported by Jeffries, Hoskins, and Sleisenger (1961).

With the introduction of methods for the direct assay of gastric intrinsic factor contradictory results were reported on the effect of cholinergic drugs. Ardeman, Chanarin, and Doyle (1964) found that the amount of intrinsic factor present in gastric juice after carbachol was no greater than that present before the carbachol was given. On the other hand, Jeffries,

\footnotetext{
* Member of the Scientific Staff, M.R.C. Experimental Haematology Research Unit, Wright-Fleming Institute of Microbiology, St. Mary's Hospital Medical School, London.

+ Senior Lecturer in Haematology, Department of Haematology, the Wright-Fleming Institute of Microbiology, St. Mary's Hospital Medical School, London.
}

Benjamin, and Sleisenger (1964) claimed that methacholine produced a rise in intrinsic factor output.

The purpose of this paper is to report further observations on the effect of cholinergic drugs on the secretion of intrinsic factor.

\section{Materials and Methods}

Gastric juice was collected continuously via a Ryle tube for one hour before and for one hour after administration of the substance under test. A full account of the methods for treating the samples of gastric juice and for assaying the intrinsic-factor content has been given elsewhere (Ardeman and Chanarin, $1963,1965)$. One unit of intrinsic factor has been defined as the amount that combines. with $1 \mu \mathrm{mg}$. of vitamin $\mathbf{B}_{12}$.

Subjects Studied.-Observations with the cholinergic drugs were made on 20 medical students and one patient with duodenal ulceration. In all, observations were made on 34 medical students, 25 patients with duodenal ulceration, and 38 other hospital patients.

Compounds Tested.-(1) Carbachol was given to 10 subjects in a $0.25-\mathrm{mg}$. dose, and to four in a $0.5-\mathrm{mg}$. dose. The larger 